\title{
WHERE IS THE SOUTHERN BOUNDARY OF FENNOSCANDIA?
}

\author{
VACHESLAV S. KULIKOV
}

KULIKOV, VACHESLAV S., 1995. Where is the southeastern boundary of Fennoscandia? Bull. Geol. Soc. Finland 67, Part II, 73-75.

Vacheslav S. Kulikov, Karelian Research Centre, Russian Academy of Science, Pushkinskaya Street 11, Petrozavodsk, 185 610, Russia.

About one hundred years ago the Finnish geologist Wilhelm Ramsay introduced the term Fennoscandia for the region in Northern Europe characterized by the geological, physicogeographical and ecological similarities of its territories [1]. The region encompassed Norway, Sweden, Finland, the Kola Peninsula, Russian Karelia, the northern part of the former Russian provinces of Olonets and the western part of Archangel. To the north, west and south, Fennoscandia is washed by the White Sea, the Barents Sea, the Norwegian Sea, the North Sea and the Baltic Sea. The southeastern land boundary of Fennoscandia was not precisely determined. According to some authors [2, 3, 4], it coincides with the boundary of the crystalline Baltic Shield. The mapping, geological prospecting, large-scale drilling and research undertaken in recent years by SEVZAPGEOLOGIA, ARCHANGELGEOLOGIA, the Karelian Research Centre and other organisations have shown that the Baltic Shield Russian Plate boundary is fairly complex and predominantly erosional $[5,6]$. Everywhere it is covered by tens of metres of unconsolidated Quaternary sediments and is not exposed. Therefore, a geological criterion such as the shield-plate contact can hardly be used to determine the southeastern boundary of Fennoscandia. Moreover it is entirely inapplicable to other parts of the region such as Sweden and Norway where Palaeozoic sediments occur.

To retain the geological and geographical integrity of the region, which has some unique characteristics, and to delimit it on the basis of natural features apparent in the field, the following criteria could be used:

1. The boundary must be natural.

2. It should be drawn along rivers, lakes, watersheds and other distinct natural features.

3. Water bodies should be used as a principal 


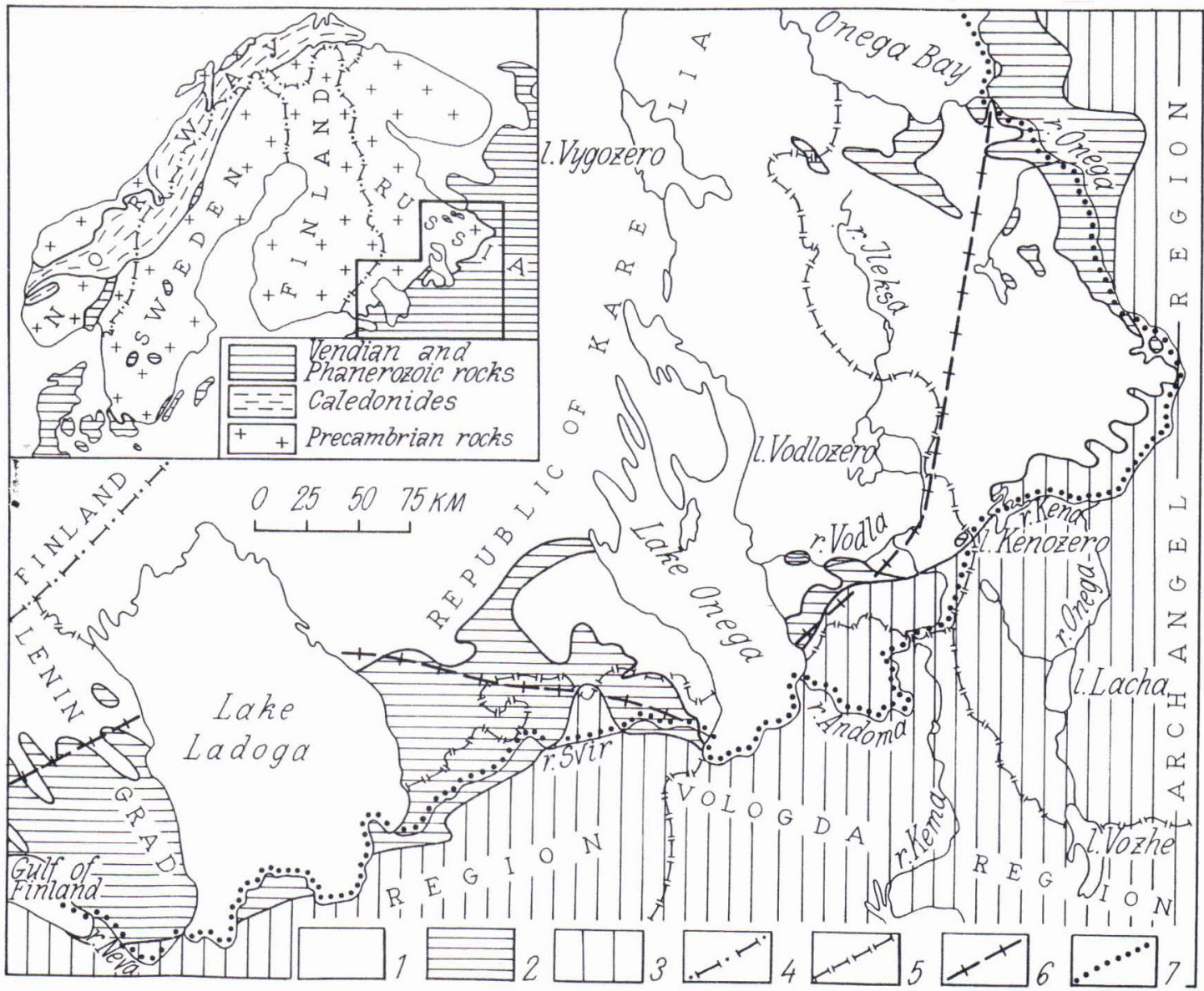

Fig. 1. Scheme showing the southeastern boundary of Fennoscandia. 1 - Precambrian crystalline rocks of the Baltic Shield (3.5 - $1.5 \mathrm{Ga}$ ); 2 - Vendian (Upper Proterozoic), weakly metamorphosed units (650 - 570 Ma); 4 - Russia/Finland border; 5 - borders between the regions of the Russian Federation; 6 Fennoscandia - Russian Plain boundary [1]; 7 - boundary of Fennoscandia proposed by the author. The geological background is presented according to [5, 6] with some author's comments.

diagnostic feature. It is known that the shores of the adjacent seas account for about $85 \%$ of boundary length. Therefore, on land the boundary could be drawn along watercourses and lake shores.

On the basis of the above criteria, the boundary of Fennoscandia between the Gulf of Finland an the White Sea Onega Bay must extend as follows: River Neva - southern shore of Lake Ladoga - River Svir - southern shore of lake Onega - River Andoma - the boundary strip - cut through the forest to separate the Republic of Karelia from the Russian Vologda and Archangel districts along the watershed of the Andoma Upland (the watershed of Baltic, White and Caspian Sea basins) - Lake Tambichorezo - River Tambicha - Lake Kenozero - River Kena - River Onega (Fig. 1).

The boundary actually stretches along the large water courses aligned along the rim of the Baltic Shield. Thus only an $80 \mathrm{~km}$ segment $(1.3 \%$ of the total length of Fennoscandia's boundary) coincides with the generalized watershed line established historically and marked in the 18th century by a strip of clear-cut in the forest to 
separate the former district and the later republic from adjacent territories. In this case, Russian Fennoscandia becomes larger than $[1,2,4]$ by encompassing the territory lying on the southeastern slope of the Baltic Shield. Such an addition of areas with a Vendian and Palaeozoic cover is also intended to emphasize the common feature of the latter because Palaeozoic rocks are also present in the western and southern parts of the region.

Within the new boundaries Fennoscandia covers an area of about 1.5 million square kilometres, including Norway $\left(324.6 \mathrm{~km}^{2}\right)$, Sweden $\left(450 \mathrm{~km}^{2}\right)$,

\section{REFERENCES:}

[1] Ramsay, W. 1898. Uber die geologische Entwicklung der Halbinsel Kola in der Quartarzeit. Fennia 16, 1-151.

[2] Sederholm, J. J. 1932. On the Geology of Fennoscandia with Special Reference to the Pre-Cambrian, Explanatory Notes to Accompany a General Geological Map of Fennoscandia. Bulletin de la Commission Geologique de Finlande 98, 30 pp.

[3] Polkanov, A. A. 1956. Geologiya hoglandiya-yotniya
Finland $\left(337 \mathrm{~km}^{2}\right)$, Russia $\left(372 \mathrm{~km}^{2}\right.$ : Karelian Republic - $172.4 \mathrm{~km}^{2}$, Murmansk region - $145 \mathrm{~km}^{2}$, Leningrad region - $28.4 \mathrm{~km}^{2}$, Archangel region $22.5 \mathrm{~km}^{2}$, Vologda region $-3.8 \mathrm{~km}^{2}$ ). It has population around 22 million, including 4.5 million in the Russian part. Russian Fennoscandia is divided by the White Sea into a northern part (Murmansk region) and a southern part (Karelia and adjacent areas). These may be referred to as Northeastern and Southeastern Fennoscandia respectively. The latter term will help avoid the use of the names of four regions of the Russian Federation mentioned above.

Baltiyskogo shchit. Trudy LAGED AN SSSR, vyp. 6, $112 \mathrm{pp}$.

[4] Tochenov V. V. (ed.) 1984. Atlas SSSR. GUGK. M. $259 \mathrm{pp}$.

[5] Koistinen, T. (ed.) 1994. Pre-Cambrian basement of the Gulf of Finland and surrounding area (Map 1: 1 000000 ). The Geological Survey of Finland.

[6] Stratiskyi, J. G. \& Udalova, A. A. (eds) 1987. Metallogenicheskaya karta usskoy platformy (Map 1: 2500 000). L. VSEGEI. 